\title{
Teaching Mode Reform of the Art Courses under the Perspective of MOOC
}

\author{
Zhou Ling \\ Hubei Engineering University, Dept. of Visual Design \\ Pukyong National University \\ Xiaogan, China
}

\author{
Cho Joung-Hyung \\ Dept. of industrial Design \\ Pukyong National University \\ Busan, South Korea
}

\begin{abstract}
The teaching reform of art courses under the MOOC mode solves many problems in teaching of open courses and activates the classroom atmosphere, realizing the innovative development of art course teaching. This paper bases on the development status of art course teaching and explores the teaching thinking and methods of art courses and the innovation of expression forms, so as to provide reference for art students to plan and improve the learning methods.
\end{abstract}

Keywords-MOOC mode; art; major courses; teaching reform

\section{INTRODUCTION}

MOOC is a popular global open teaching mode in recent years. Under the online development mode, more than 1.9 million people from 196 countries register and learn. With the abundant learning resources, students can learn courses of domestic and foreign famous universities through smart phones and tablet PC. MOOC resources expand the width and depth of the design thinking of students. In practical teaching, teachers of art and design major should encourage students to acquire more professional knowledge through the network and promote the benign development of classroom teaching.

\section{The DEVElopment StATUS OF THE ART COURSES TEACHING}

For local application-oriented colleges, the system of art courses is in the critical period to adjust the specialty structure and reform the course system. Restricted by the teaching staff construction, the funding for school management and the talent training, the construction of art major meets problems and challenges. Firstly, on the course design and teaching of art major, the training objective is vague, the major setup is unreasonable and the practical teaching lacks guidance, resulting in the uneven quality of talent training. Secondly, the arrangement system of art courses is unsound. The characteristics of main courses and the optional courses cannot be highlighted. The courses are dispersed. Besides, in the curriculum provision, the class hours of required courses are inadequate. For example, there are 16 hours for the course of logo design weekly. The total hour is 64 in four weeks. The class hour is insufficient in theory explanation and practice

This paper is the teaching research project of Hubei Engineering University: Teaching Mode Reform of the Art Courses under the Perspective of MOOC-Take the course of Text Design as an example, project number: 2015 A 11. link of the logo design. Thirdly, defects exist in the teaching contents and practice demands. Taking the POP design course as an example, the manuscript POP has been unable to meet the current design requirements. With the emergence and development of computer font software, the POP font is enrolled in the font object library. We can print and make easily on the computer. Therefore, it is necessary to improve and update the teaching contents of art courses, in order to better adapt to the development and requirements of teaching at present.

\section{TEACHING INNOVATION OF ART COURSES UNDER THE MOOC MODE}

\section{A. Innovation of Teaching Thinking}

The traditional art courses focus on the classroom teaching. Because the information acquired on the textbook is limited, students finish the original sketch design through searching the design information on the network. In the course of font design, the classroom teaching centers on the handwritten characters. Students have to grasp the boldface, Song typeface, English and Arabic numerals from the format to the strokes and the filling of ink. The training method has great limitations. On one hand, it wastes time in drawing the grids; on the other hand, it goes against the adjustment of fonts through writing on the paper. The online template of MOOC breaks the limitation. The template of font writing enables students to pay more attention to the stroke patterns of the fonts as well as liberates the complexity of handwriting characters, laying a foundation for the research and creation of font forms.

\section{B. Innovation of Teaching Methods}

The teaching methods and equipment for the traditional art courses should be advanced in design. With the development of times, the new teaching tools and equipment update continuously. Similarly, the teaching methods should improve correspondingly. In the teaching practice, teachers should center on the heuristic teaching and guide students to use the network resources of MOOC, extensively collecting design information and drawing sketch design freehand, to open students' thinking through the design features and seeking the innovation points. Under the teaching model of MOOC, combine the contents of art courses with the online practice to train students' practical ability and innovation ability and integrate design theories and methods in the online design 
practice, so as to strengthen students' harmonious development in theory and skills. In the classroom teaching of character design, I combine the theme of text texture with the character forms and express the experimental character forms through stones, branches and silk in the nature, promoting and displaying the good font effects on the network platform. The teaching method provides more opportunities for students to carry out design practice and digest the theoretical knowledge in practice, realizing the virtuous cycle of learning and practice.

\section{Innovation of the Teaching Expression Form}

The innovation of teaching is also the innovation of vision and the process of seeking "generality" and "personality". The traditional classroom teaching reform is single and centers on the teaching materials through PPT, difficult to arouse students' enthusiasm. Smart phone addicts can be seen everywhere. MOOC teaching mode provides remote learning support, changes the single teaching and centers on students, making use of the advantages of network and classroom. Students can learn online through choosing various high quality resources on the network platforms and observe the latest academic trends and discuss the learning experience in class. On one hand, it activates the classroom atmosphere; on the other hand, it links up the learning links and promotes students to absorb the related knowledge. In the classroom teaching of character design, I make the best of the unique font object library provided by the MOOC and change the popular research into the personalized research of characters. Both static text and dynamic text are unique. The online resources make up for the deficiencies of teaching materials. The theories in textbook also supplement the theoretical research of the online resources, so that the significant teaching effects can be achieved.

\section{Prospect For the TeACHING Reform OF ART COURSES UNDER THE MOOC MODE}

The art education should center on the construction of characteristic courses. Different schools should have different artistic style, base on the open theory on school management and take the talent training objective as the guidance to improve the construction of teaching staff and the teaching conditions of art courses. Besides, they should also deepen the reform of practical teaching, make the best of the teaching and network resources of MOOC and integrate teaching, learning with practice, combining the network practice with the classroom teaching and learning the advanced design philosophy from the world-class masters, meanwhile, use the practice information on the network to link up the design and practice.

\section{CONCLUSION}

As the pioneer of online education mode, MOOC provides abundant learning resources and promotes the reform and innovation of modern teaching means. Therefore, we should reasonably make use of the methods in MOOC resources and actively explore the lively and interesting teaching mode of courses in order to improve students' professional learning ability in comments and feedback. In the teaching reform of art courses, we should adhere to the open theory on school management and explore the effective teaching methods through the MOOC platform, improving and innovating continuously in practice.

\section{REFERENCES}

[1] Li Qing, Wang Tao. MOOC: A Massive Open Online Course Mode Based on the Connectionism [J], Distance Education in China, 2012(3)

[2] Wang Ping. New Development and Application of the Massive Open Online Course: From CMOOC to XMOOC [J], Modern Distance Education Research, 2013

[3] Wang Wenli. The Development of MOOC and Its Influence on the Higher Education [J], Jiangsu Higher Education, 2013(2)

[4] Li Hui. Analysis on the Current Situation of Excellent Network Courses and Exploration on Countermeasures [J], China Education Info, 2007(4) 69-71

[5] Chen Jin. Ten Years of the Open Access [M], Beijing: National Library of China Publishing House, 2012 